\title{
ANALISIS EFEKTIVITAS PENGELOLAAN KEUANGAN DAERAH PADA BADAN PENGELOLA KEUANGAN, ASET DAN PENDAPATAN DAERAH (BPKAPD) KOTA BAUBAU
}

\author{
Dewi Mahmuda \\ Program Studi Akuntansi, Fakultas Ekonomi \\ Universitas Muhammadiyah Buton, Baubau, Indonesia \\ e-mail: dwmahmuda@gmail.com
}

\begin{abstract}
ABSTRAK
Penelitian ini bertujuan untuk untuk menganalisis efektivitas pengelolaan keuangan daerah pada Badan Pengelola Keuangan, Aset Dan Pendapatan Daerah (BPKAPD) Kota Baubau Penelitian dilakukan di selama bulan Agustus sampai dengan September tahun2018. Metodeanalisis data yang digunakan adalah metode deskriptif kualitatif. Hasil penelitian menunjukkanbahwa rasio kemandirian Pemerintah Kota Baubau tahun 2015 sampai 2017 belum dapat dikatakan sebagai daerah yang mandiri dalam mengelola keuangan daerahnya. Rasio kemandirian di Kota Baubau selama tahun 2015, 2016 dan 2017 adalah masing-masing sebesar 10,79\%, 12.65\%.dan 11,82\%. Sedangkan rasio efektivitas menunjukkan tingkat kemampuan keuangan daerah sangat efektif. Terbukti dengan hasil perhitungan rasio kemandirian selama tahun 2015, 2016 dan 2017 adalah masing-masing sebesar $102,79 \%$., $119,97 \%$ dan $102,29 \%$.
\end{abstract}

\section{Kata Kunci: Pengelolaan Keuangan Daerah, Efektivitas.}

\begin{abstract}
This study aims to analyze the effectiveness of regional financial management in financial, asset and regional revenue management departement of baubau city (BPKAPD). The study was conducted from August to September 2018.The analysis method that is used is descriptive qualitative method. The results showed that the independence ratio of the Baubau City Government in 2015 to 2017 could not be said to be an independent area in managing the regional finances. The independence ratios in Baubau City during 2015, 2016 and 2017 were 10.79\%, 12.65\% and 11.82\% respectively. While the effectiveness ratio shows the level of regional financial capability is very effective. Evidenced by the results of the calculation of the independence ratio during 2015, 2016 and 2017 were 102.79\%, $119.97 \%$ and $102.29 \%$ respectively.
\end{abstract}

Keywords: Regional Financial Management, Effectiveness. 


\section{PENDAHULUAN}

Penerapan otonomi daerah sebagai upaya untuk mendukungpenyelenggaraan pemerintahan daerah secara proporsional diwujudkan denganperaturan pembagian dan pemanfaatan sumber daya daerah yang berkeadilan,serta perimbangan keuangan antara pemerintah pusat dan daerah sebagai sumberpembiayaan pemerintah dan pembangunan daerah. Lebih khusus bahwa undang-undang nomor 33 tahun 2004 tentang perimbangan keuangan antara pemerintahpusat dan daerah adalah suatu sistem pembiayaan pemerintahan dalam kerangkaNegara Kesatuan Republik Indonesia yang mencakup pembagian keuangan antarapemerintah pusat dan daerah serta pemerataan antar daerah secara proporsional,demokratis, adil dan transparan dengan memperhatikan potensi, kondisi dankebutuhan daerah sejalan dengan kewajiban dan pembagian kewenangan serta tatacara penyelenggaraan kewenangan tersebut [1].

Berangkat dari pemahaman demikian, maka untuk menghadapi berbagaipersoalan seperti kemiskinan, pemerintah daerah tidak bisa lagi menggantungkan penanggulangannya kepada pemerintah pusat sebagaimana yang selama iniberlangsung.Di dalam kewenangan otonomi yang dipunyai daerah, melekat pula tanggung jawab untuk secara aktif dan secara langsung mengupayakan pengentasan kemiskinan di daerah bersangkutan. Dengan kata lain, pemerintah daerah dituntut untuk memiliki inisiatif kebijakan operasional yang bersifat pro-masyarakat miskin [2].

Hubungan antara otonomi daerah dengan desentralisasi, demokrasi dantata pemerintahan yang baik memang masih merupakan diskursus. Banyakpengamat mendukung bahwa dengan dilaksanakannya otonomi daerah maka akanmampu menciptakan demokrasi atau pun tata pemerintahan yang baik di daerah.

Berkaitan dengan kewenangan dan tanggung jawa dalam pelaksanaan otonomi daerah, maka pemerintah daerah berupaya dengan membuat dan melaksanakan berbagai kebijakan dan regulasi yang berkenaan dengan hal tersebut. Namun dengan belum adanya bentuk yang jelas dalam operasionalisasi otonomi tersebut,maka sering terdapat bias dalam hasil yang di dapat. Pelimpahan kewenangan dalam otonomi cenderung dianggap sebagai pelimpahan kedaulatan.Pada kondisi ini, otonomi lebih dipahami sebagai bentuk redistribusi sumber ekonomi/keuangan dari pusat ke daerah. Hal ini terutama bagi daerah-daerah yangkaya akan sumber ekonomi. Dengan begitu, konsep otonomi yang seharusnya bermuara pada pelayanan publik yang lebih baik, justru menjadi tidak atau belumterpikirkan [3]. 
Kemandirian daerah sering diukur dari kemampuan daerah dalam meningkatkan Pendapatan Asli Daerah (PAD). PAD juga menjadi cerminan keikutsertaan daerah dalam membina penyelenggaraan pemerintahan, pembangunan, dan pelayanan kemasyarakatan di daerah [4]. Keleluasaan memunculkan inisiatif dan kreativitas pemerintah daerah dalam mencari dan mengoptimalkan sumber penerimaan dari PAD sekarang ini cenderung dilihat sebagai sumber prestasi bagi pemerintah daerah bersangkutan dalam pelaksanaanotonomi. Disamping itu, hal ini dapat menimbulkan pula ego kedaerahan yanghanya berjuang demi peningkatan PAD sehingga melupakan kepentingan lainyang lebih penting yaitu pembangunan daerah yang membawa kesejahteraan bagimasyarakatnya [5]. Euphoria reformasi dalam pelaksanaan pemerintahan di daerahseperti ini cenderung mengabaikan tujuan otonomi yang sebenarnya.

Otonomi menjadi keleluasaan daerah untuk menyelenggarakan kewenangan pemerintah di bidang tertentu yang secara nyata ada dan diperlukan serta hidup, tumbuh, dan berkembang di daerah. Sedangkan otonomi yang bertanggung jawab adalah perwujudan pertanggung jawaban sebagai konsekuensi pemberian hak dan kewenangan daerah dalam wujud tugas dan kewajiban yangharus dipikul oleh daerah dalam mencapai tujuan pemberian otonomi, yaitu peningkatan pelayanan dan kesejahteraan masyarakat yang semakin baik, pengembangan kehidupan demokrasi, keadilan, dan pemerataan, sertapemeliharaan hubungan yang serasi antara pusat dan daerah serta antar daerah [4].

Berdasarkan semangat otonomi daerah dan tuntutan pemerintahan yangbaik, maka diharapkan kepada setiap pemerintah daerah dan lebih khusus pemerintah daerah kota Baubau agar dalam menjalankan tugas dan wewenang pembangunan daerah utamanya yang menyangkut dengan pengelolaan anggaran pendapatan dan belanja daerah (APBD) agar semaksimal mungkin meningkatkan fungsi pengawasan secara efisien dan efektif dalam rangka membangun pemerintahan daerah yang governance demi mewujudkan cita-cita pembangunan nasional di daerah.

\section{METODE PENELITIAN}

Populasi adalah wilayah generalisasi yang terdiri atas objek/subjek yang mempunyai kualitas dan karakteristik tertentu yang ditetapkan oleh peneliti untuk dipelajari kemudian ditarik kesimpulan [6]. Populasi dalam penelitian ini adalah laporan realisasi anggaran pemerintah kota Baubau Tahun 2015 sampai dengan tahun 2017. Sampel 
dalam penelitian ini adalah laporan pertanggungjawaban penggunaan anggaran pada Badan Pengelola Keuangan, Aset Dan Pendapatan Daerah (BPKAPD) Kota Baubau 2015 sampai dengan tahun 2017.

Jenis data yang digunakan adalah data kualitatif dan data kuantitatif.Dalam penelitian ini yang termasuk data kualitatif yaitu gambaran umum tentang Badan Pengelola Keuangan, Aset Dan Pendapatan Daerah (BPKAPD) Kota Baubaumeliputi: sejarah singkat berdirinya, visi dan misi, struktur organisasi, dan lain-lain.Sedangkan yang termasuk data kuantitatif yaitu laporan pertanggungjawaban penggunaan anggaran pada Badan Pengelola Keuangan, Aset Dan Pendapatan Daerah (BPKAPD) Kota Baubau Tahun 2015 sampai tahun 2017.

Data primer adalah data yang diperoleh peneliti langsung dari objek penelitiannya. Data sekunder adalah data yang diperoleh dalam bentuk jadi, telah diolah, dan yang telah dipublikasikan [6]. Data yang dibutuhkan dalam penelitian ini akan dikumpulkan dengan beberapa metode, yaitu metode observasi, dokumentasi, dan wawancara.

Metode analisis yang digunakan dalam penelitian ini adalah analisis deskriptif kualitatif. Analisis deskriptif kualitatif yaitu dengan memberikan ulasan atau interpretasi terhadap data yang diperoleh sehingga menjadi lebih jelas dan bermakna dibandingkan dengan sekedar angka-angka. Tahapan yang dilakukan dalam analisis deskriptif kualitatif adalah:Reduksi data (data reduction), Penyajian data (data display), dan menarik kesimpulan (verifikasi), sebagai proses mencari arti, mencatat keteraturan, pola-pola, penjelasan, konfigurasi-konfigurasi yang mungkin, alur sebab akibat dan proporsiproporsi penelitian[6].

\section{HASIL DAN PEMBAHASAN}

\section{a. Hasil Penelitian}

Tujuan umum laporan keuangan adalah menyajikan informasi mengenai posisi keuangan, realisasi anggaran, arus kas dan kinerja keuangan suatu entitas pelaporan yang bermanfaat bagi para pengguna dalam membuat dan mengevaluasi keputusan mengenai alokasi sumber daya [7].

Setiap tahunnya anggaran pemerintah daerah tersebut diakumulasi untuk melihat jumlah besaran dana yang diterima dan dikeluarkan untuk keperluan pemerintah daerah dan juga pembangunan daerahnya, baik dari segi pendapatan maupun segi pengeluaran. Adapun uraian dari pendapatan tersebut dapat dilihat dari 
pendapatan asli daerah dan dana perimbangan yang diterima. Untuk uraian pengeluaran dapat dilihat dari belanja operasi, belanja modal, dan belanja tak terduga. Sehingga dari sana dapat diketahui surplus atau defisit dari anggaran Pemerintah daerah setiap tahunnya.

Berikut ini adalah laporan realisasi angaran belanja daerah Badan Pengelola Keuangan, Aset dan Pendapatan Daerah Kota Baubau Tahun 2015 sampai dengan tahun 2017.

Tabel 1. Laporan Realisasi Anggaran Tahun 2015-2017

\begin{tabular}{|lr|r|r|}
\hline \multirow{2}{*}{ Uraian } & \multicolumn{3}{c|}{ Tahun } \\
\cline { 2 - 4 } Pendapatan Asli Daerah & \multicolumn{1}{c|}{$\mathbf{2 0 1 7}$} & \multicolumn{1}{c|}{$\mathbf{2 0 1 6}$} & \multicolumn{1}{c|}{$\mathbf{2 0 1 5}$} \\
\hline Pendapatan Transfer & $84,452,098,000$ & $92,381,551,000$ & $72,124,772,000$ \\
\hline Belanja Operasi & $714,640,227,000$ & $730,454,621,000$ & $668,386,050,000$ \\
\hline Belanja Modal & $212,721,765,000$ & $296,502,196,000$ & $193,442,672,000$ \\
Belanja Tak Terduga & $627,193,550,000$ & $689,236,120,000$ & $601,126,335,000$ \\
\hline Surplus/Defisit & $5,805,000,000$ & $2,201,900,000$ & $2,153,899,200$ \\
\hline
\end{tabular}

Sumber: BPKAD Kota Baubau (Data Diolah)

Dari tabel tersebut diketahui bahwa jumlah pendapatan yang diperoleh selama 3 tahun terakhir cukup bervariasi. Pada tahun 2015 jumlah pendapatan yang masuk adalah sebesar Rp.72.124.772.000 dari pendapatan asli daerah dan Rp668.386.050.000 dari pendapatan transfer. Jumlah ini meningkat pada tahun 2016 yakni seebsar Rp92.381.551.000 dari pendapatan asli daerah dan Rp.730.454.621.000 dari pendapatan transfer. Kemudian pada tahun 2017 jumlah pendapatan yang masuk menurun menjadi Rp. 84.452.088.000 dari pendapatan asli daerah dan Rp.714.640.227.000 dari pendapatan transfer.

Pada aktivitas belanja pemerintah juga mengalami kenaikan dan penurunan selama 3 tahun terakhir. Pada tahun 2016 belanja operasi, belanja modal dan belanja tak terduga adalah masing-masing sebesar Rp.193.442.672.000, Rp. 601.126.335.000 dan Rp.2.153.212.084.000. Untuk tahun 2015, secara keseluruhan jumlah belanja pemerintah mengalami peningkatan. Belanja operasi sebesar Rp.296.502.196.000, belanja modal sebesar Rp. 689.236.120.000 dan belanja tak terduga sebesar Rp.2.201.900.000. Sedangkan untuk tahun 2017 jumlah belanja operasi sebesar Rp.212.721.765.000, belanja modal sebesar Rp. 627.193.550.000 dan belanja tak terduga sebesar Rp. 5.805.000.000. 
Dari data tersebut peneliti akan menganalisis efektivitas pengelolaan keuangan pada Badan Pengelola Keuangan, Aset dan Pendapatan Daerah Kota Baubau Tahun 2015 sampai dengan tahun 2017. Untuk menilai efektivitas pengelolaan keuangan tersebut dapat dilihat dari rasio kemandirian dan rasio efektifitas.

\section{Analisis Rasio Kemandirian}

Rasio kemandirian menggambarkan ketergantungan daerah terhadap sumber dana ekstern. Semakin tinggi rasio kemandirian daerah, tingkat ketergantungan terhadap bantuan pihak ekstern (terutama pemerintah pusat dan provinsi) semakin rendah, dan sebaliknya [8]. Rasio Kemandirian Pemerintah Kota Baubau selama tahun 2015 sampai tahun 2017 adalah sebagai berikut:

a. Tahun 2015

Rasio Kemandirian $=\frac{\text { PAD Tahun } 2015}{\text { Pend.Transfer Tahun } 2015} \times 100 \%$

Rasio Kemandirian $=\frac{72.124 .772 .000}{668.386 .050 .000} \times 100 \%$

Rasio Kemandirian $=10,79 \%$

b. Tahun 2016

Rasio Kemandirian $=\frac{\text { PAD Tahun } 2016}{\text { Pend.Transfer Tahun } 2016} \times 100 \%$

Rasio Kemandirian $=\frac{92.381 .551 .000}{730.454 .621 .000} \times 100 \%$

Rasio Kemandirian $=12,65 \%$

c. Tahun 2017

Rasio Kemandirian $=\frac{\text { PAD Tahun } 2017}{\text { Pend.Transfer Tahun } 2017} \times 100 \%$

Rasio Kemandirian $=\frac{84.452 .088 .000}{714.640 .227 .000} \times 100 \%$

Rasio Kemandirian $=11,82 \%$ 
Dari hasil perhitungan tersebut di atas diketahu bahwa rasio kemandirian keuangan pemerintah Kota Baubau dalam tiga tahun terakhir (2015-2017) cukup bervariasi. Pada tahun 2015 rasio kemandirian yang di hasilkan yaitu sebesar 10,79\%. Pada periode tahun 2016 rasio kemandirian mengalami kenaikan sebesar 0,86\% sehingga menjadi 12.65\%. Pada tahun 2017 rasio kemandirian turun sebesar 0,17\% sehingga menjadi $11,82 \%$.

\section{Tabel 2. Pola Hubungan Tingkat Kemandirian dan Keuangan Daerah}

\begin{tabular}{|c|c|}
\hline Kemampuan Keuangan & Rasio Kemandirian \\
\hline Rendah sekali & $0-25 \%$ \\
\hline Rendah & $25-50 \%$ \\
\hline Sedang & $50-75 \%$ \\
\hline Tinggi & $75-100 \%$ \\
\hline
\end{tabular}

Berdasarkan hasil dari perhitungan rasio kemandirian Pemerintah Kota Baubau ini menggambarkan tingkat kemampuan keuangan daerah masih sangat rendah sekali. Terbukti dengan hasil perhitungan rasio kemandirian selama tahun 2015, 2016 dan 2017 adalah masing-masing sebesar 10,79\%, 12.65\%.dan 11,82. Ketiga nilai ini berada pada kategori rendah yaitu antara $0-25 \%$. Hal ini berarti bahwa peranan Pemerintah Pusat lebih dominan dari pada kemandirian Pemerintah Daerah. Dengan kata lain pemerintah daerah Kota Baubau masih sangat bergantung pada dana perimbangan yang berasal dari pusat.

\section{Rasio Efektivitas Pendapatan Asli Daerah}

Rasio efektifitas menggambarkan kemampuan Pemda dalam merealisasikan Pendapatan Asli Daerah (PAD) yang direncanakan dibandingkan target yang ditetapkan berdasarkan potensi riil daerah. Kemampuan daerah dalam menjalankan tugas dikategorikan efektif apabila rasio yang dicapai minimal sebesar 1 (satu) atau 100 persen.Semakin tinggi rasio efektivitas menggambarkan kemampuan daerah yang semakin baik [9].Berikut adalah data realisasi penerimaan pendapatan asli daerah (PAD) dan target penerimaan pendapatan asli daerah (PAD selama tahun 2015 sampai tahun 2017. 
Tabel 3. Target dan Realisasi PAD

\begin{tabular}{|l|c|l|}
\hline Tahun & Target PAD & Realisasi PAD \\
\hline 2017 & 82.153 .591 .000 & 84.452 .088 .000 \\
\hline 2016 & 77.294 .711 .000 & 92.381 .551 .000 \\
\hline 2015 & 70.503 .646 .000 & 72.124 .772 .000 \\
\hline
\end{tabular}

Sumber: BPKAD Kota Baubau (Data Diolah)

Berdasarkan data tersebut di atas, maka rasio kemandirian selama tahun 2015, 2016 dan 2017 adalah sebagai berikut:

a. Tahun 2015

Rasio Efektivitas $=\frac{\text { Realisasi PAD Tahun } 2015}{\text { Target PAD Tahun } 2015} \times 100 \%$

Rasio Efektivitas $=\frac{84.452 .088 .000}{82.153 .591 .000} \times 100 \%$

Rasio Efektivitas $=102,79 \%$

b. Tahun 2016

Rasio Efektivitas $=\frac{\text { Realisasi PAD Tahun } 2016}{\text { Target PAD Tahun } 2016} \times 100 \%$

Rasio Efektivitas $=\frac{92.381 .551 .000}{77.294 .711 .000} \times 100 \%$

Rasio Efektivitas $=119,97 \%$

c. Tahun 2017

Rasio Efektivitas $=\frac{\text { Realisasi PAD Tahun } 2017}{\text { Target PAD Tahun } 2017} \times 100 \%$

Rasio Efektivitas $=\frac{72.124 .772 .000}{70.502 .646 .000} \times 100 \%$

Rasio Efektivitas $=102,29 \%$ 
Dari hasil perhitungan tersebut di atas diketahui bahwa rasio efektivitas pengelolaan keuangan pemerintah Kota Baubau dalam tiga tahun terakhir (20152017) cukup bervariasi. Pada tahun 2015 rasio efektivitas yang di hasilkan yaitu sebesar 102,79\%. Pada periode tahun 2016 rasio efektivitas mengalami kenaikan sebesar 17,18 \% sehingga menjadi 119,97\%. Pada tahun 2017 rasio kemandirian turun sebesar 17,07\% sehingga menjadi 102,29\%.

\section{Tabel 4. Kriteria Efektivitas Pendapatan Asli Daerah}

\begin{tabular}{|l|c|}
\hline \multicolumn{1}{|c|}{$\begin{array}{c}\text { Kemampuan } \\
\text { Keuangan }\end{array}$} & Rasio Kemandirian \\
\hline Sangat efektif & Lebih dari 100\% \\
\hline Efeketif & $100 \%$ \\
\hline Cukup efektif & $90-99 \%$ \\
\hline Kurang efektif & $75-89 \%$ \\
\hline Tidak efektif & Kurang dari $75 \%$ \\
\hline
\end{tabular}

Berdasarkan hasil dari perhitungan rasio efektivitas ini menggambarkan tingkat kemampuan keuangan daerah sangat efektif. Terbukti dengan hasil perhitungan rasio kemandirian selama tahun 2015, 2016 dan 2017 adalah masingmasing sebesar 102,79\%., 119,97\% dan 102,29\%. Hal ini berarti bahwa peranan kemampuan Pemerintah Kota Baubau dalam merealisasikan PAD yang direncanakan dibandingkan target yang ditetapkan berdasarkan potensi riil daerah.

\section{b. Pembahasan}

Efektivitas pengelolaan keuangan dalam penelitian ini selalin dihitung dengan menggunakan rasio efektivitas juga dihitung dengan rasio kemandirian.Menurut [10], kemandirian keuangan daerah (otonomi fiskal) menunjukan kemampuan pemerintah daerah dalam membiayai sendiri kegiatan pemerintah, pembangunan dan pelayanan kepada masyarakat yang telah membayar pajak dan retribusi sebagai sumber pendapatan yang diperlukan daerah. Kemandirian keuangan daerah ditunjukan oleh besar kecilnya pendapatan asli daerah dibandingkan dengan pendapatan daerah yang berasal dari sumber yang lain, misalnya bantuan pemerintah pusat ataupun dari pinjaman. 
Rasio kemandirian menggambarkan ketergantungan daerah terhadap sumber dana ekternal. Semangkin tinggi rasio kemandirian mengandung arti bahwa tingkat ketergantungan daerah terhadap bantuan pihak ekternal (terutama pemerintah pusat dan propinsi) semangkin rendah, dan demikian juga sebaliknya.Rasio kemandirian juga menggambarkan tinggkat partisipasi masayarakat dalam pembayar pajak dan restribusi daerah yang merupakan komponen utama pendapatan asli daerah. Semangkin tinggi masyarakat membayar pajak dan restribusi daerah akan menggambarkan tinggkat kesejateraan masyarakat yang semangkian tinggi.

Hasil penelitian dari perhitungan rasio kemandirian pemerintah Kota Baubau melalui Badan Pengelola Keuangan, Aset dan Pendapatan Daerah Kota Buabau menunjukkan tingkat kemampuan keuangan daerah masih sangat rendah sekali.

Karena tingkat kemandirian di Kota Baubau selama tahun 2015, 2016 dan 2017 adalah masing-masing sebesar 10,79\%, 12.65\%.dan 11,82\%. Ketiga nilai ini berada pada kategori rendah yaitu antara $0-25 \%$. Hal ini berarti bahwa peranan Pemerintah Pusat lebih dominan dari pada kemandirian Pemerintah Daerah. Dengan kata lain pemerintah daerah Kota Baubau masih sangat bergantung pada dana perimbangan yang berasal dari pusat

Kemandirian berarti mampu mencukupi kebutuhan pembiayaan untuk melakukan tugas-tugas pemerintahan dan pembangunan dengan mengandalkan pendapatan asli daerahnya sendiri dari pada bantuan pihak eksternal.Semakin tinggi rasio kemandirian berarti semakin tinggi pendapatan asli daerah danketergantungan bantuan terhadap pihak eksternal semakin rendah.Rendahnya kontribusi Pendapatan Asli Daerah (PAD) tersebut disebabkan oleh rendahnya kesadaran masyarakat dalam membayar pajak serta lemahnya pengelolaan pemerintah terhadap kekayaan daerah yang tidak produktif sehingga tidak dapat menghasilkan Pendapatan Asli Daerah (PAD) yang maksimal. Sehingga dapat dikatakan bahwa Kota Baubau masih sangat bergantung dengan bantuan dari dana perimbangan atau bantuan dari pemerintah pusat.

Rasio efektifitas menggambarkan kemampuan pemerintah daerah dalam merealisasikan pendapatan asli daerah yang direncanakan dibandingkan dengan target yang ditetapkan berdasarkan potensi rill daerah yang ada sudah sangat efektif. Kemampuan daerah dalam menjalankan tugas dikategorikan efektif apabila yang dicapai mencapai minimal sebesar 1 (satu) atau 100 persen.Namun demikian semakin 
tinggi rasio efektifitas, menggambarkan kemampuan daerah yang semangkin baik[10].Hasil perhitungan dari Rasio Efektifitas Pendapatan Asli Daerah (PAD) tahun 2015, 2016 dan 2017 adalah masing-masing sebesar 102,79\%., 119,97\% dan $102,29 \%$. Hal ini berarti bahwa peranan kemampuan Pemerintah Kota Baubau dalam merealisasikan PAD yang direncanakan dibandingkan target yang ditetapkan berdasarkan potensi riil daerah.

Capaian tersebut menunjukkan bahwa realisasi Pendapatan Asli Daerah (PAD) lebih besar dibandingkan dengan anggaran/target yang telah ditetapkan pada tahun yang bersangkutan dan jika dilihat capaian bahwa realisasi Pendapatan Asli Daerah (PAD) mengalami penurunan, ini berarti bahwa anggaran Pendapatan Asli Daerah (PAD) lebih rendah dari capaian/realisasi Pendapatan Asli Daerah (PAD) tahun yang bersangkutan sehingga kondisi keuangan pemerintah dikategorikan tidak efektif. Hal ini berarti menunjukkan kinerja yang positif bagi Kota Baubau dalam merealisasikan PAD yang telah ditargetkan.Kemampuan Kota Baubau dalam meraup PAD yang telahditargetkan menandakan di Kota Baubau masih memilikibanyak sumber PAD yang apabila bisa dioptimalkan dengan baik dapatmembantu tugas - tugas pemerintahan dan pembangunan. Sehingga tercipta keserasian antara program besar pemerintah pusat yang didukung dnegan program penting pembangunan di penjuru daerah di Indonesia.

\section{KESIMPULAN}

Analisis efektivitas pengelolaan keuangan pada Badan Pengelola Keuangan, Aset dan Pendapatan Daerah Kota Baubau tahun 2015 sampai tahun 2017 dianalisis dengan menggunakan dua perhitungan rasio, yaitu rasio kemandirian dan rasio efektivitas.

Rasio kemandirian Pemerintah Kota Baubau tahun 2015 sampai 2017 belum dapat dikatakan sebagai daerah yang mandiri dalam mengelola keuangan daerahnya, karena masih sangat rendah sekali dalam kemandirian disebabkan rendahnya Pendapatan Asli Daerah yang dihasilkan dibanding dengan transfer dari pemerintah Pusat dan Provinsi. Rasio kemandirian di Kota Baubau selama tahun 2015, 2016 dan 2017 adalah masingmasing sebesar 10,79\%, 12.65\%.dan 11,82\%. Ketiga nilai ini berada pada kategori rendah yaitu antara $0-25 \%$. Hal ini berarti bahwa peranan Pemerintah Pusat lebih 
dominan dari pada kemandirian Pemerintah Daerah. Dengan kata lain pemerintah daerah Kota Baubau masih sangat bergantung pada dana perimbangan yang berasal dari pusat.

Rasio efektivitas ini menggambarkan tingkat kemampuan keuangan daerah sangat efektif. Terbukti dengan hasil perhitungan rasio kemandirian selama tahun 2015, 2016 dan 2017 adalah masing-masing sebesar 102,79\%., 119,97\% dan 102,29\%. Hal ini berarti bahwa peranan kemampuan Pemerintah Kota Baubau dalam merealisasikan PAD yang direncanakan dibandingkan target yang ditetapkan berdasarkan potensi riil daerah.

\section{SARAN}

Adapun saran yang dapat disampaikan oleh penulis berdasarkan hasil penelitian adalah agar Pemerintah Kota Baubau dapat lebih mengoptimalkan sumber - sumber pendapatan asli daerah (PAD) yang belum maksimal realisasinya, seperti pada pajak retribusi daerah yaitu pada izin mendirikan bangunan serta izin retribusi tempat penginapan, dengan semakin banyaknya bangunan yang berdiri serta bertambahnya penginapan tentunya akan menambah jumlah PAD pada sektor tersebut dan pendapatan lain - lain yang sah yaitu penerimaan jasa giro yangsetiap tahunnya realisasi pendapatannya tidak stabil. mencapai target PAD tersebut. Dengan semakin meningkatnya PAD yang didapat oleh suatu daerah terlebih dapat melampaui target yang dicapai, membuktikan kinerja Pemerintah Daerah Kota Baubau sudah sangat efektif, apalagi apabila target dari penerimaan PAD tersebut dapat meningkat setiap tahunnya.

\section{DAFTAR PUSTAKA}

[1] Republik Indonesia. Undang-Undang Nomor 33 Tahun 2004 tentang Perimbangan Keuangan antara Pemerintah Pusat dan Pemerintahan Daerah.

[2] Wiranto, Tatag. 2004. Pembangunan Wilayah Pesisir dan Laut dalam Kerangka Pembangunan Perekonomian Daerah.Makalah dipresentasikan pada Sosialisasi Nasional Program MFCDP, Septermber 22, Jakarta.

[3] Jati, Wasisto Raharjo. 2012 Inkonsistensi Paradigma Otonomi Daerah di Indonesia: Dilema Sentralisasi atau Desentralisasi. Jurnal Konstitusi, Volume 9, Nomor 4.

[4] Republik Indonesia, Undang-Undang Nomor 23 Tahun 2014 tentang Pemerintah Daerah.

[5] Noviades, Dhils. 2013. Pengelolaan Keuangan Daerah di Era Otonomi Daerah, Jurnal Ilmu Hukum Jambi, Volume 4, Nomor 1. 
[6] Sugiyono. 2010. Metode Penelitian Bisnis. Bandung: CV ALFABETA

[7] Hariadi, Pramono, Yanuar Restiano, Icuk Bawono. 2010. Pengelolaan Keuangan Daerah. Jakarta: Salemba Empat.

[8] Halim, Abdul. 2008. Manajemen Keuangan Daerah, Edisi Revisi. UPP AMD YKPN.

[9] Munir, dkk. 2004. Kebijakan dan Manajemen Keuangan Daerah. Yogyakarta: YPAPI.

[10] Halim, Abdul. 2013. Akuntansi Sektor Publik. Akuntansi Keuangan Daerah. Yogyakarta: UPP AMD YKPN. 